\title{
DNA damage activates p53 through a phosphorylation-acetylation cascade
}

\author{
Kazuyasu Sakaguchi, ${ }^{1}$ Julio E. Herrera, ${ }^{2}$ Shin'ichi Saito, ${ }^{3}$ Toru Miki, $^{3}$ Michael Bustin, ${ }^{2}$ \\ Alex Vassilev, ${ }^{4}$ Carl W. Anderson, ${ }^{5,6}$ and Ettore Appella ${ }^{1}$ \\ ${ }^{1}$ Laboratory of Cell Biology, ${ }^{2}$ Laboratory of Molecular Carcinogenesis, and ${ }^{3}$ Laboratory of Cellular and M olecular Biology, \\ $\mathrm{N}$ ational Cancer Institute ( $\mathrm{NCl}$ ), ${ }^{4}$ Laboratory of Molecular Growth Regulation, $\mathrm{N}$ ational Institute of Child Health and \\ Devel opment, N ational Institutes of Health, Bethesda, M aryland 20892 USA; ${ }^{5}$ Biology Department, Brookhaven N ational \\ Laboratory, U pton, N ew York 11973 USA
}

\begin{abstract}
Activation of p53-mediated transcription is a critical cellular response to DNA damage p53 stability and site-specific DNA-binding activity and, therefore, transcriptional activity, are modulated by post-translational modifications including phosphorylation and acetylation. Here we show that p53 is acetylated in vitro at separate sites by two different histone acetyltransferases (HATs), the coactivators p300 and PCAF. p300 acetylates Lys-382 in the carboxy-terminal region of p53, wherees PCAF acetylates Lys-320 in the nuclear localization signal. Acetylations at either site enhance sequence-specific DNA binding. Using a polyclonal antisera specific for $\mathrm{p} 53$ that is phosphorylated or acetylated at specific residues, we show that Lys-382 of human p53 becomes acetylated and Ser-33 and Ser-37 become phosphorylated in vivo after exposing cells to UV light or ionizing radiation. In vitro, amino-terminal p53 peptides phosphorylated at Ser-33 and/or at Ser-37 differentially inhibited p53 acetylation by each HAT. These results suggest that DNA damage enhances p53 activity as a transcription factor in part through carboxy-terminal acetylation that, in tum, is directed by amino-terminal phosphorylation.
\end{abstract}

[Key Words: CBP/p300; PCAF; histone acetyltransferase; DNA-PK; transcriptional activation; checkpoints]

Received April 3, 1998; revised version accepted July 24, 1998.

The p53 tumor suppressor is a critical component of cellular mechanisms that respond to certain stresses to preserve genomic integrity by arresting cell-cycle progression or by inducing apoptosis (Levine 1997; Agarwal et al. 1998). p53 normally is a short-lived protein that is maintained at low levels, but in response to DN A-damaging agents, nucleotide depletion, or hypoxia, the p53 protein is transiently stabilized and accumulates in the nucleus in which it functions in part to induce or repress the transcription of several genes including WAF1 (EIDeiry et al. 1993), SFN (Hermeking et al. 1997), and MDM2 (Juven et al. 1993; Perry et al. 1993) that regulate cell-cycle progression. The Mdm2 protein binds the amino terminus of $\mathrm{p} 53$ and functions in an autoregulatory loop that attenuates p53 activity by directly sequestering its transactivation domain (Oliner et al. 1993; Wu et al. 1993). M dm2 also targets p53 for degradation and, therefore, may play a critical role in regulating its accumulation in response to DN A damage (Haupt et al . 1997; Kubbutat et al. 1997). The segment of p53 that interacts with $M d m 2$, which encompasses the region between Glu-17 and Pro-27, includes two potential phosphoryla-

${ }^{6}$ Corresponding author.

E-MAIL cwa@bnl.gov; FAX (516) 344-3407. tion sites, Thr-18 and Ser-20, and is surrounded by several other potential phosphorylation sites including Ser9, Ser-15, Ser-33, and Ser-37 (M eek 1998). Phosphorylation of $\mathrm{p} 53$ by DNA-PK, a DN A-activated protein kinase that phosphorylates p53 at Ser-15 and Ser-37 in vitro (Lees-Miller et al. 1992), was reported to inhibit the interaction with M dm2 (Shieh et al. 1997), as does phosphorylation of the amino terminus of Mdm2 by DNAPK (M ayo et al. 1997). Phosphorylation of Ser-15 in vivo is stimulated by DN A-damaging agents including ionizing radiation (IR) and UV. These recent findings suggest that amino-terminal phosphorylation may be one of the signals regulating the p53 response to DNA damage (Shieh et al. 1997; Siliciano et al. 1997).

In addition to causing p53 to accumulate, DNA damage is widely believed to activate p53 as a transcription factor through post-translational mechanisms. In support of this hypothesis, microinjection of damaged DN A or a monoclonal antibody to the carboxyl terminus of p53 activated p53-specific transcription and induced p53-dependent cell-cycle arrest under conditions in which no increase in p53 protein was detected (Hupp and Lane 1995; Huang et al. 1996). Furthermore, in mouse fibroblasts, UV-C activated p53's DN A-binding activity in $G_{0}$ and $G_{1}$ without causing p53 accumulation (Haapajärvi et al. 1997; Pitkänen et al. 1998). p53 has two DN Abinding domains, a sequence-specific DNA-binding do- 
main encompassing amino acid residues $\sim 100-300$ that interacts with the consensus sequence element 5'RRRCWWGYY-(N) 1-13-RRRCWWGYY-3' (Funk et al. 1992), and a non-sequence-specific DNA-binding domain corresponding to the carboxy-terminal $\sim 100$ amino acids (300-393) that include the tetramerization domain (Pavletich et al. 1993; Wang et al. 1993). M odifications to the carboxy-terminal domain, including deletion of the last 30 amino acids (Hupp et al. 1992), protein binding (Hupp et al. 1992), phosphorylation of Ser-315, Ser-378, and Ser-392 (Hupp and Lane 1995; T akenaka et al. 1995; Wang and Prives 1995), and most recently, acetylation by CREB-binding protein (CBP)/p300 (Gu and Roeder 1997) were shown to enhance sequence-specific DNA-binding of wild-type p53, possibly by inhibiting p53's non-sequence-specific DNA-binding activity (Anderson et al. 1997). CBP and p300 are closely related histone acetyltransferases (HATs) that interact with p53 through its amino terminus and function as coactivators for p53mediated transcription (Avantaggiati et al. 1997; Lill et al. 1997). CBP/p300 are complexed with another HAT, p300/CBP-associated factor PCAF (Yang et al. 1996). These recent findings suggest that activation of sequence-specific DNA-binding by p53 in response to DN A damage may be mediated through CBP/p300 and/ or PCAF; however, a direct connection between DNA damage and activation of sequence-specific DNA-binding has not been made.

In this study, we present evidence that activation of sequence-specific DN A-binding by p53 after DN A damage depends on a signal transduction cascade involving phosphorylation-mediated p53 acetylation by the coactivator, p300. We confirm Gu and Roeder's observation (1997) that p300 acetylates the carboxyl terminus of p53 in vitro, and show that PCAF acetylates p53 in vitro on Lys-320. Using antisera specific for each of the acetylated forms of p53, we show that Lys-382 is acetylated in response to both IR and UV light in vivo; p53 also became acetylated at Lys-320 after exposure of cells to UV. Acetylation by $\mathrm{p} 300$ and PCAF was strongly inhibited by phosphopeptides corresponding to the amino terminus of p53 phosphorylated at Ser-37 and/or Ser-33, and these residues were phosphorylated in response to UV and IR in vivo. These findings suggest that phosphorylations in response to DNA damage enhance the interaction of p300 and PCAF with p53, thereby driving p53 acetylation.

\section{Results}

PCAF and p300 acetylate p53

p53 is modified in vivo at amino- and carboxy-terminal sites by post-transl ational modifications including phosphorylation and acetylation. To determine whether the acetylation of Iysine residues may contribute to regulating p53 activity, we incubated wild-type human p53 with recombinant PCAF or p300, two well-characterized HATs. In agreement with the findings of $\mathrm{Gu}$ and Roeder (1997), p300 acetylated full-length p53 (Fig. 1C). Al-

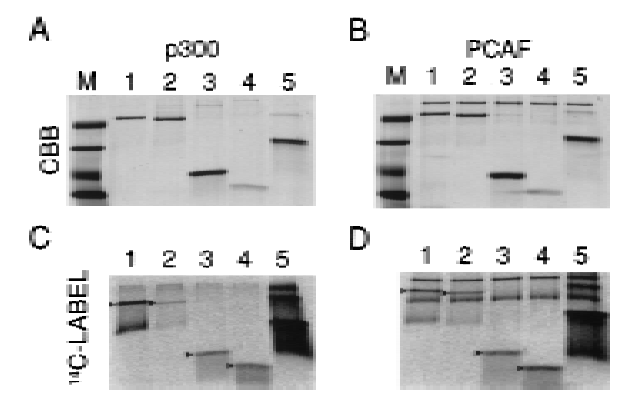

Figure 1. Acetylation of $p 53$ and p53 fragments by $p 300$ and PCAF. Wild-type human p53 or truncated p53 fragments were acetylated with either PCAF or p300 at $37^{\circ} \mathrm{C}$ for $20 \mathrm{~min}$ as described in $M$ aterials and $M$ ethods, and the reaction products were analyzed by SDS-PAGE. P300 acetylation $\left({ }^{14} \mathrm{C}\right.$-Label) is depicted in the radioactive image in $\mathrm{C}$; the corresponding $\mathrm{CoO}$ massie brilliant blue-stained image (CBB) is in A. PCAF acetylation is in $D$; the corresponding Coomassie brilliant bluestained image is in $\mathrm{B}$. Histone $\mathrm{H} 1$ served as a positive control for acetylation (Herrera et al. 1997). (Lanes M) Molecular weight markers; (lanes 1) full-length wild-type, baculovirus-produced human p53; (lanes 2) p53(1-355); (lanes 3) p53(283-393); (lanes 4) p53(318-393); (lanes 5) histone H1.

though some acetylation was seen also with the fragment p53(1-355), the major site of acetylation was in the carboxy-terminal domain [i.e., in p53(283-393) and p53(318-393)], as observed by Gu and Roeder (1997). Interestingly, similar results were obtained with PCAF (Fig. 1D); full-length p53, p53(283-393) and p53(318-393) all were acetylated, whereas a construct lacking the carboxyl terminus, p53(1-355), was acetylated less efficiently.

To identify the sites acetylated in the carboxyl terminus of p53, Escherichia coli-expressed p53(319-393) was acetylated with either p300 or PCAF, and the fragments were repurified. Ion spray mass spectrometry of the p53 fragment modified by either enzyme gave two major products that differed by 42 mass units and could be unambiguously interpreted (Fig. 2). The lower molecular weight product $(A)$ in each case corresponded to the mass of the unmodified p53 product; the higher molecular weight component corresponded to the p53 product acetylated at a single site. $\mathrm{M}$ inor shoulders resulting from oxidation of methionine to the sulfoxide also were seen $\left(\mathrm{A}^{\mathrm{O}}\right.$ and $\left.\mathrm{B}^{\mathrm{O}}\right)$. N otably, however, there was no product with a mass corresponding to a doubly acetylated product.

To identify the sites of acetylation, each product was digested with trypsin, and the tryptic fragments were analyzed by nanospray ion trap mass spectrometry (Fig.

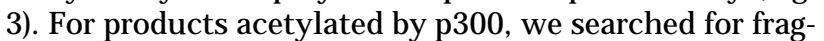
ments with masses corresponding to all predicted acetylated tryptic peptides. One such fragment was observed, corresponding to the tryptic fragment Lys-382-Lys-386 with a $\mathrm{m} / \mathrm{z}$ [mass (in Daltons) divided by the charge] of 708 (Fig. 3A). All expected collision-induced ion products corresponding to the tryptic fragment acetylated at Lys-382 were observed, and these were inconsistent with the masses expected from acetylation at Lys-386. That 


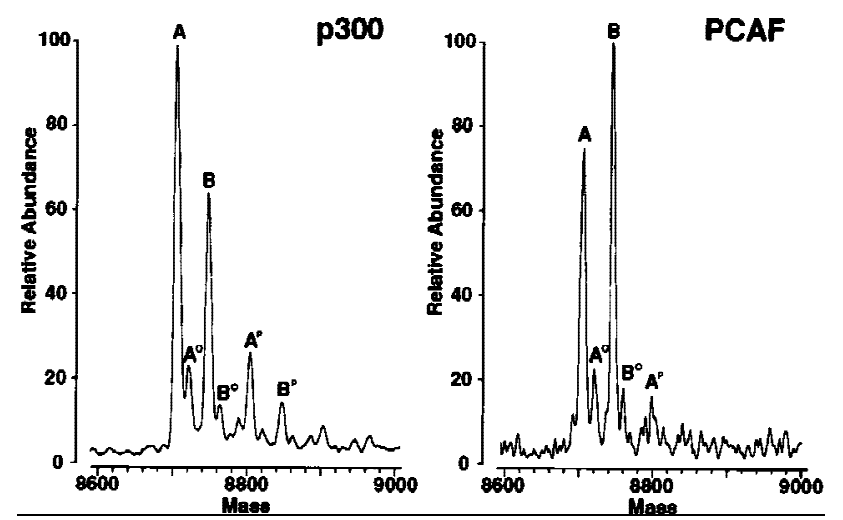

Figure 2. p300 and PCAF each acetylate a single site in the carboxyl terminus of human p53. E. coli expressed p53(319-393) was acetylated with either p300 or PCAF, and the repurified fragments were analyzed by ion spray mass spectrometry. The mass profiles are shown. The major peak labeled $A$ in each case corresponds to the mass of the unmodified p53 fragment (8707); the major peak label ed B is larger by 42 mass units, corresponding to the addition of one acetate residue. N o mass was observed at the position expected for diacetylated or higher acetylated forms. $M$ inor shoulders result from oxidation of methionine to the sulfone $\left(A^{0}\right.$ and $\left.B^{0}\right)$ and formation of the phosphate salt $\left(A^{p}\right.$ and $\mathrm{B}^{\mathrm{p}}$.

the acetylation site is Lys-382 was confirmed by analyzing the synthetical ly prepared acetylated peptide, which gave a mass fragmentation pattern identical to that of the p300 acetylated product (data not shown). A similar analysis was carried out on the p53 fragment acetylated by PCAF. Only one fragment was observed with a mass corresponding to that expected for an acetylated tryptic fragment, and this mass $(1750 \mathrm{~m} / \mathrm{z}$ ) corresponded to p53 tryptic fragment Lys-320-Arg-333 (Fig 3B). Although this peptide al so contains two lysine residues, analysis of the collision-induced fragments was consistent only with acetylation of one position, corresponding to Lys-320 in full-length $\mathrm{p} 53$.

To determine whether acetylation was affected by the phosphorylation or oligomerization state of the p53 carboxyl terminus, chemically synthesized fragments were prepared with phosphate incorporated either at Ser-378, a predicted site of phosphorylation by protein kinase $C$ (PKC) (Hupp and Lane 1995; Takenaka et al. 1995), or Ser-392, a site phosphorylated in vitro by casein kinase 2 (CK2) (Meek 1998). We also prepared peptides with alanines replacing residues Leu-323, Tyr-327, and Leu-330 [p53(319-393)AAA ] in the tetramerization domai $n$; these substitutions prevent the formation of p53 oligomers (Sakamoto et al. 1994). For p300, phosphorylation at either site had no effect on acetylation, and the monomer form of the carboxy-terminal fragment also was acetylated well by p300 (Fig. 4C, lane 4). In the case of PCAF, however, acetylation depended critically on the ability of the fragment to form tetramers (Fig 4D, lane 4), and phosphorylation at Ser-378 strongly inhibited acetylation (Fig. 4D, lane 5), whereas phosphorylation at Ser-392 had no significant effect (Fig. 4D, lane 3).
Acetylation by $p 300$ and PCAF activate sequence-specific DNA-binding

Several modifications to the carboxy-terminal region of p53, including phosphorylation by CK2, PKC, and Cdc2 kinases and truncation of the last 30 residues, modulate the ability of p53 to bind its recognition site through the central sequence-specific DN A-binding domain (Hupp et al. 1992; Hupp and Lane 1995; Takenaka et al. 1995). To determine whether acetylation by $\mathrm{p} 300$ and PCAF al so affect sequence-specific DNA-binding, full-length p53 was incubated with either recombinant p300 or recombinant PCAF, and the reaction products were used in a DNA gel mobility shift assay described by Anderson et al. (1997) with a synthetic double-stranded probe containing the p53-binding site (Funk et al. 1992). In the absence of competitor DNA, some binding of the probe to wild-type p53 was observed (Fig. 5A, lane 2), but binding of untreated p53 was completely suppressed by the presence of nonspecific pBluescript competitor DNA (Fig. 5, lane 5). After incubation with either p300 or PCA F and acetyl-CoA, strong binding of $\mathrm{p} 53$ to the probe was observed both in the absence (Fig. 5, lanes 3,4) and the presence of competitor pBluescript, (Fig. 5, lanes $6,10)$. Strong binding also was observed with p53 that was incubated sequentially in either order with p300 and PCAF and acetyl-CoA (Fig. 5, lanes 14,15). Although a small amount of binding was observed either when ace tyl-CoA was omitted or when it was replaced by unacetylated CoA (Fig. 5, lanes 7,8,11,12), this amount was substantially less than in the presence of acetyl-CoA, indicating that acetylation and not simply binding of either p300 or PCAF to p53 was necessary for the effect on DNA-binding. Analysis of the extent of acetylation in parallel reactions with $\left[{ }^{14} \mathrm{C}\right]$ acetyl-CoA showed that more acetate was incorporated in the presence of p300 than PCAF (Fig 5B). Quantitation of these results suggests that acetylation at either site enhances sequencespecific DNA binding to similar extents.

The p300 and PCAF sites are acetylated in vivo in response to DNA damage

To determine whether p53 is acetylated in vivo, we prepared polyclonal antisera specific for each acetylation site (Materials and Methods). Figure 6 shows that the PAbLys(Ac)382 antibody, prepared with a peptide corresponding to p53(377-387)Cys acetylated at Lys-382, recognized p53 acetylated by p300 but not unacetylated p53 nor p53 acetylated by PCAF. Likewise, the PAbLys(Ac)320 antibody, prepared with a peptide corresponding to p53(315-325)Cys acetylated at Lys-320, recognized p53 acetylated by PCAF, but not unacetylated p53 nor p53 acetylated by p300. After incubation with both HATs and acetyl-CoA, p53 was recognized by both anti bodies. These results indicated that the PAbLys(A c)382 antibody is highly specific for the acetylated form of p53 produced by $\mathrm{p} 300$, and the PAbLys(Ac) 320 antibody is highly specific for p53 acetylated by PCAF; neither antibody recognizes p53 acetylated at the nonhomologous 


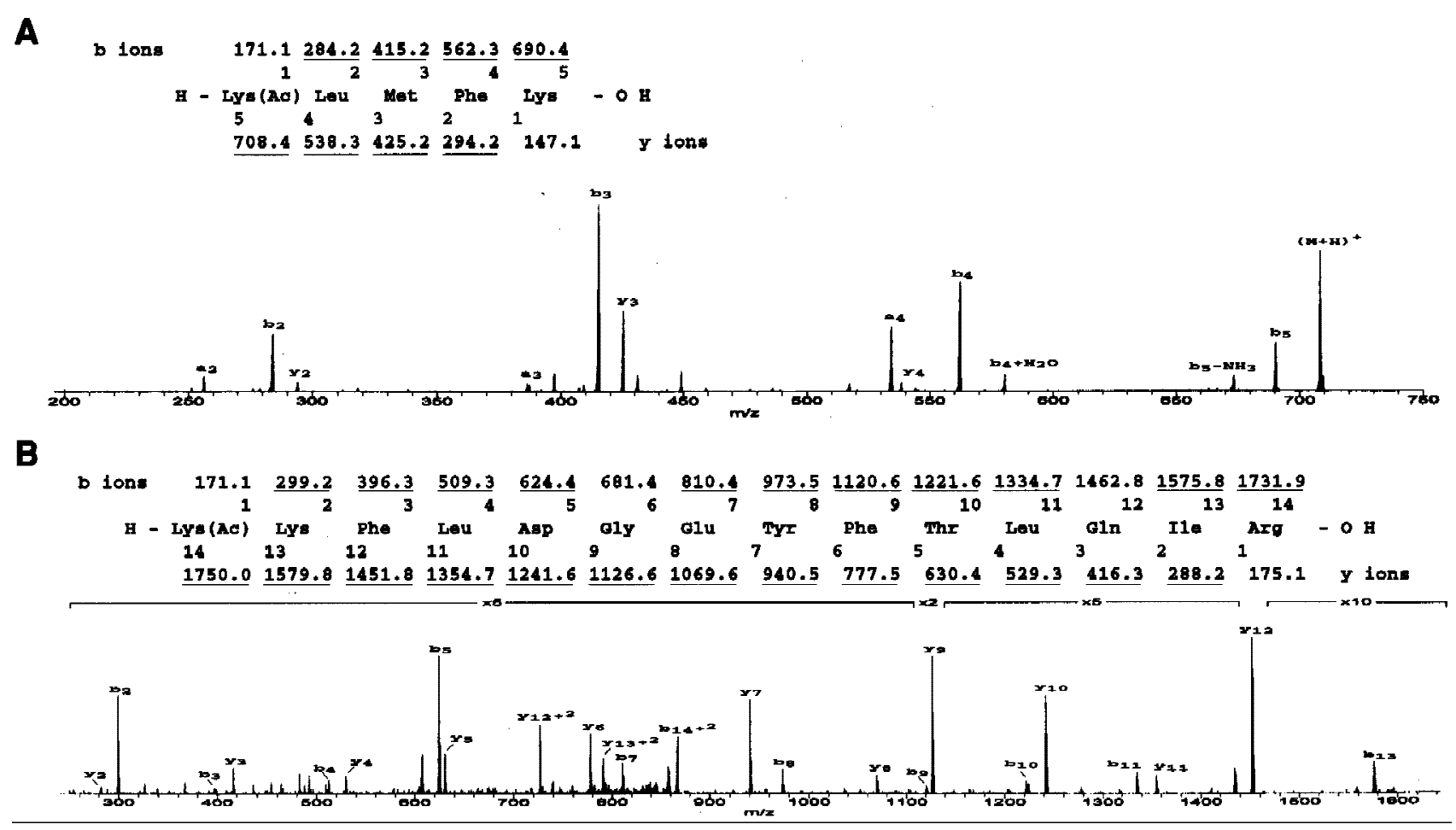

Figure 3. Identification of the p53 sites acetylated by PCAF and p300. (A) p53(319-393) acetylated by p300 was digested with trypsin and the peptide products were analyzed by nanospray ion trap mass spectrometry. (Bottom) The fragmentation mass spectrum for the acetylated peptide of $\mathrm{m} / \mathrm{z}$ 708. The mass of the acetylated tryptic product corresponds to that of monoacetylated p53(382-386). (Top) The sequence and expected $\mathrm{m} / \mathrm{z}$ values of fragmentation products. Observed ions are underlined. The fragmentation pattern is consistent only with acetylation of Lys-382 and identical to synthetic p53(382-386) with Lys-382 acetylated. (B) p53(319-393) acetylated by PCAF was digested with trypsin and the peptide products were analyzed by nanospray ion trap mass spectrometry. (Bottom) The fragmentation mass spectrum for the acetylated peptide of doubly charged ion of $\mathrm{m} / \mathrm{z} 876$. Segments of the profile were expanded in thedirection of the $y$-axis by 2-, 5-, or 10-fold as indicated. The mass of the acetylated tryptic product corresponds to that of monoacetylated p53(320-333). (Top) The sequence and expected $\mathrm{m} / \mathrm{z}$ val ues of fragmentation products. Observed ions are underlined. The fragmentation pattern is consistent only with acetylation of Lys-320 and identical to synthetic p53(320-333) with Lys-320 acetylated.

site. The specificity of each antibody al so was confirmed by ELISA assay with synthetically prepared p53 fragments (data not shown). Affinity-purified polyclonal antibodies specific for $p 53$ phosphorylated at Ser-33 or Ser37 were prepared similarly. By ELISA, the PAbSer(P)33 antibody reacted with p53[27-39(33P)Cys] and p53[139(33P)] but not with p53(25-65), p53(1-39), p53(139) phosphorylated at Ser-9, Ser-15, Ser-20, or Ser-37; the PAbSer $(\mathrm{P}) 37$ antibody reacted with peptides $\mathrm{p} 53[1-$ 39(37P)] and p53[25-65(37P)] but not with p53(1-39), p53[1-39(15P)], or p53(25-65) (data not shown).

We used the p53 acetylation-specific antibodies to examine p53 from normal and DNA-damaged cells. The human cell lines A 549 and HCT 116, both of which have wild-type p53, were exposed to $25 \mathrm{~J} / \mathrm{m}^{2} \mathrm{UV}-\mathrm{C}$ or $8 \mathrm{~Gy}$ $\gamma$-rays (IR), and extracts were prepared at different times after treatment. As a control, cells were treated with 20 $\mu \mathrm{M}$ ALLN, a proteasome inhibitor that partially stabilizes p53, thus causing its accumulation to levels similar to those obtained after treatment with DNA damageinducing agents. To prevent rapid deacetylation of p53, trichostatin A (TSA), an inhibitor of histone deacety- lases, was added at the time of exposure (Yoshida et al. 1990). After harvesting the cells, p53 was immunoprecipitated from the extracts and analyzed by Western blotting. Figure 7 shows the effect on A549 cells. As expected, exposure to UV light induced the accumulation of p53 in both cell lines, which was apparent by $4 \mathrm{hr}$ and continued to increase until $24 \mathrm{hr}$ after treatment. IR treatment induced a rapid accumulation of p53 that was readily evident at $2 \mathrm{hr}$ and reached a maximum between 4 and $8 \mathrm{hr}$, and then declined. ALLN also induced an accumulation of p53, detected with the DO-1 monoclonal antibody, that was maximal in the $8 \mathrm{hr}$ sample and then declined to approximately the level in untreated cells by $24 \mathrm{hr}$. No signal was visible from untreated cells with either the PAbLys(Ac)382 or the PAbLys(Ac)320 anti body, suggesting that neither site is si gnificantly acetylated in undamaged cells. Furthermore, neither antibody gave a signal with p53 from ALLN -treated cells, indicating that the lack of a signal in untreated cells did not result from the lower amount of p53 in those samples and that stabilization and accumulation al one did not result in acetylation of p53. Significantly, a strong signal 
A

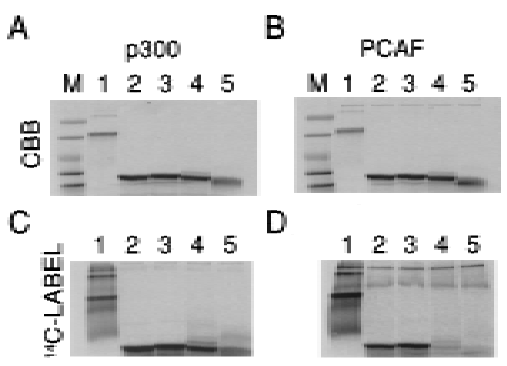

Figure 4. Acetylation of mutant and phosphorylated p53 carboxy-terminal fragments by PCAF and P300. Chemically synthesized, unmodified p53(319-393), p53(319-393) with phosphoserine incorporated at either Ser-392 or Ser-378, or p53(319393) with alanine replacing each of the three tetramerization domain residues Leu-323, Tyr-327, and Leu-330 [p53(319393)AAA ] were acetylated with p300. The radioactive image $\left({ }^{14} \mathrm{C}\right.$-Label) is shown in C; the corresponding Coomassie brilliant blue (CBB)-stained image is in A. PCAF acetylation is in D; the corresponding Coomassie brilliant blue-stained image is in B. Histone $\mathrm{H} \mathrm{I}$ served as a positive control for acetylation. (Lanes M) Molecular weight markers; (lanes 1) histone $\mathrm{H} 1$; (lanes 2) unmodified p53(319-393); (lanes 3) p53(319-393) phosphorylated at Ser-392; (lanes 4) p53(319-393) phosphorylated at Ser378; (lanes 5) tetramerization mutant p53(319-393)AAA.

was obtained with the PAbLys(Ac)382 antibody in samples harvested $24 \mathrm{hr}$ after exposure to either UV light or IR, and this signal was clearly visible as early as $2 \mathrm{hr}$ after IR exposure and at $4 \mathrm{hr}$ after exposure to UV. Similar results were obtained for HCT116 cells exposed to UV light (data not shown). For A549 cells, a similar but weaker signal was obtained with the PAbLys(Ac)320 antibody that was clearly visible $4 \mathrm{hr}$ after exposure to UV light but was seen only at $24 \mathrm{hr}$ after exposure to IR (Fig. 7). Phosphorylation at Ser-37, a site potentially phosphorylated in response to DNA damage (Lees-Miller et al. 1992; Shieh et al. 1997), was detected with the PAb-
$\operatorname{Ser}(\mathrm{P}) 37$ antibody at $4 \mathrm{hr}$ after exposure to IR, but the signal rapidly decayed and was not visible by $8 \mathrm{hr}$. Phosphorylation at Ser-37 al so was seen at $4 \mathrm{hr}$ after exposure to UV light, coincident with the appearance of acetylation but, in this instance, the signal increased over the next $20 \mathrm{hr}$ (Fig. 7, bottom). These results indicated that p53 is acetylated at Lys-382 in response to either IR or UV light and at Lys-320 after exposure to UV light. p53 also becomes phosphorylated at Ser-37 in response to both treatments.

To examine how rapidly phosphorylation and acetylation occur after DNA damage, A549 cells were treated for $4 \mathrm{hr}$ with ALLN to induce p53 accumulation; they then were treated with $25 \mathrm{~J} / \mathrm{m}^{2} \mathrm{UV}$-C or $8 \mathrm{~Gy} \gamma$-rays and TSA, and harvested for immunoprecipitation and Western blot analysis 0, 1, 2, or $4 \mathrm{hr}$ later (Fig. 8). Acetylation of Lys-382 was cl early seen by $1 \mathrm{hr}$ after IR treatment and by $2 \mathrm{hr}$ after UV treatment. Phosphorylation of Ser-37 also was observed by $2 \mathrm{hr}$ after UV treatment, but only weakly at $4 \mathrm{hr}$ after IR treatment. However, phosphorylation of Ser-33 was strongly induced by both UV and IR as early as $1 \mathrm{hr}$ after treatment. Little, if any, phosphorylation at Ser-33 was seen in untreated cells or in ALLN treated cells.

\section{Phosphorylation influences acetylation of $\mathrm{p} 53$} by $\mathrm{p} 300$ and PCAF

The above results, in conjunction with several recent studies, suggest that p53 acetylation might be triggered through amino-terminal DNA damage-induced phosphorylations. Our finding that full-length p53 is a better substrate for p300 than a tetrameric carboxy-terminal fragment (Fig. 1) is consistent with the importance of amino-terminal p53 residues for acetylation of the carboxyl terminus. To further explore the role of phosphorylation in modulating acetylation, we investigated
A
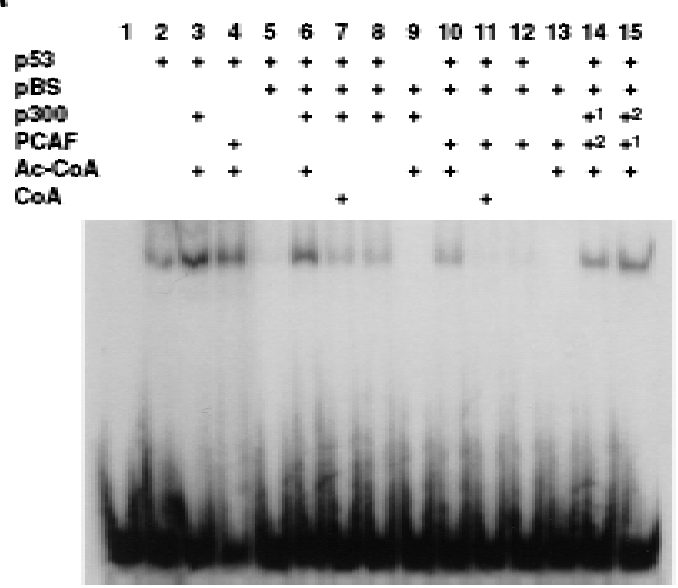

B

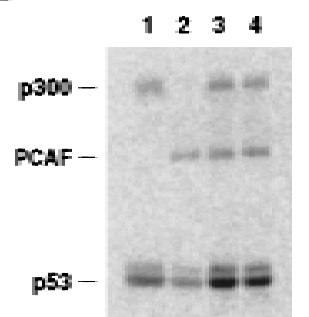

Figure 5. Activation of sequence-specific binding by acetylation of p53 with p300 and PCAF. Baculovirus-produced wild-type p53 was acetylated with p300 or with PCAF as described in Materials and $M$ ethods, and the reaction products then were used in electrophoretic mobility shift assays as described by Anderson et al. (1997). (A) Radioactive images of the EMSA gels; the ingredients present during the p53 modification reactions are indicated at top. (Lanes 14,15) The order of p300 and PCAF additions are indicated by superscripts; (lane 7,11) unacetylated COA was added in place of acetylCoA (Ac-CoA). The p53-shifted radioactive probe appears as a band near the top of the gel; free probe is at the bottom. (B) Parallel acetylation reactions were performed with ${ }^{14} \mathrm{C}$-labeled acetyl-CoA, and the reactions were fractionated by SDS-PAGE. Shown is the radioactive image of the gel. (Lane 1 ) Reaction with p53 and p300, (lane 2 ) reaction with p53 and PCAF; (lane 3 ) reaction with p53 incubated with PCAF and then also with p300; (lane 4) reaction with p53 incubated with p300 and then with PCAF. 


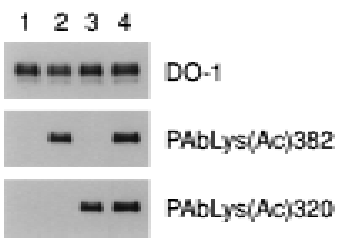

Figure 6. PAbLys(Ac)382 and PAbLys(Ac)320 recognize p53 acetylated by p300 and PCAF, respectively. Recombinant p53 was acetylated by incubation with p300, PCAF, or both, and a Western blot was prepared as described in Fig. 1. Affinity-purified rabbit polyclonal antibodies were prepared by use of acetylated peptides corresponding to sequences around Lys-382 and Lys-320 as described in Materials and Methods. The blot was probed sequentially with PAbLys(Ac)382, PAbLys(Ac)320, and DO-1, a monocl onal antibody specific for the amino terminus of p53. (Lane 1) U nacetylated p53; (lane 2) p53 incubated with p300 and acetyl-CoA; (lane 3) p53 incubated with PCAF and acetylCoA; (lane 4) p53 incubated with both p300 and PCAF and ace tyl-CoA.

the effect of phosphorylated amino-terminal p53 peptides on the ability of p300 and PCAF to acetylate fulllength p53 in vitro (Fig. 9). We reasoned that if phosphorylation were important for the interaction between p53 and either HAT, the phosphorylated peptide would inhibit acetylation of p53 better than would the unphosphorylated peptide. As shown in Figure 9, p53(1-57) inhi bited acetylation of full-length p53 by p300 or PCAF by $70 \%-90 \%$, results consistent with the observation that Trp-53 and Phe-54 are important for the interaction between p53 and p300 (Scolnick et al. 1997). In contrast, p53(1-39) was a poor inhibitor $(0 \%-15 \%)$ of acetylation by either HAT; however, p53(1-39) phosphorylated at Ser-33 or at Ser-37 inhibited p53 acetylation by either p300 or PCAF significantly better $(40 \%-80 \%)$ than did the unphosphorylated peptide. Similar results were obtained with p53(25-65) phosphorylated at Ser-37 or at both Ser-33 and Ser-37 (data not shown). Phosphorylation of p53(1-39) at other amino-terminal sites including Ser- 9 and Ser-20, but not Ser-15, inhibited acetylation by

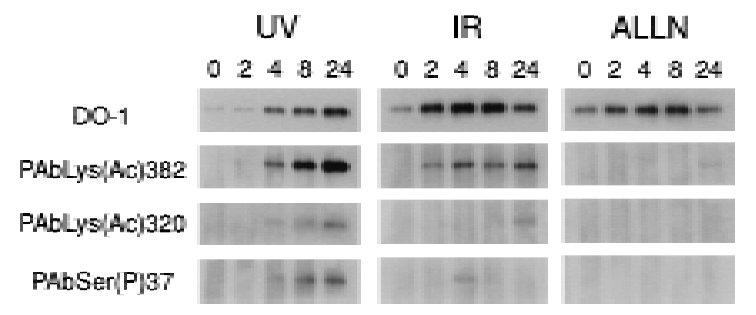

Figure 7. Induction of p53 acetylation and phosphorylation by UV, $\gamma$-rays, and ALLN. A549 cells were exposed to $25 \mathrm{~J} / \mathrm{m}^{2}$ of UV-C, 8 Gy $\gamma$-rays (IR), or treated with $20 \mu \mathrm{M}$ cal pain inhibitor I (ALLN). TSA was added to $5 \mu \mathrm{M}$ immediately after DNA damage treatment. Samples were harvested at the indicated times after initiating treatment (top of lanes), and extracts were prepared for immunoprecipitation with Pab1801, a monoclonal antibody specific for human p53, followed by Western immunoblot analysis as described in M aterials and M ethods. The Western blots were probed sequentially with PAbLys(Ac)382, PAbLys(Ac)320, PAbSer(P)37, and DO-1. p300 or PCAF to lesser extents, but still more than the unphosphorylated peptide. In contrast, none of these p53 amino-terminal peptides inhibited acetylation of a carboxy-terminal fragment of p53 (data not shown). These results suggest that amino-terminal phosphorylation may enhance the interaction of p53 with p300 and PCAF, thereby potentiating acetylations that are critical for sequence-specific DN A-binding.

In support of the above hypothesis, phosphorylation of wild-type p53 by DNA-PK enhanced the acetylation of recombinant p53 (Fig. 10). For this experiment, fulllength human p53 produced in insect cells, which was partially phosphorylated a several sites including Ser-33 (Patterson et al. 1996), but not to a significant extent at Ser-37 (Fig. 10), was incubated with DN A-PK or not, and then with p300 and acetyl-CoA. Incubation with DN APK produced a new, slower mobility p53 isoform (Fig 10, band 3) that is phosphorylated at Ser-33 and Ser-37. Although both the untreated (Fig 10, control) and DNAPK-treated p53 were acetylated by catalytic amounts of p300, after DN A-PK treatment only the slower mobility isoform (Figure 10, band 3) was acetylated. This result indicates that the DNA-PK phosphorylated isoform was acetylated over p53 isoforms that were not phosphorylated by DNA-PK but were still present, as revealed by staining with DO-1.

\section{Discussion}

Here we report that $\mathrm{p} 53$ can be acetylated in vitro by two HATs, p300 and PCAF, that function as coactivators for p53-mediated transcription in vivo. Both HATs acetylated the carboxyl terminus of p53 at single sites, Lys382 in the case of p300, and Lys-320 in the case of PCAF. Lys-382 was the major site of acetylation seen by Gu and Roeder (1997); the minor sites they identified may have resulted from their use of a relativel y short peptide as the substrate for in vitro acetylation. The rate of acetylation by p300 was significantly reduced $(-80 \%)$ by removing

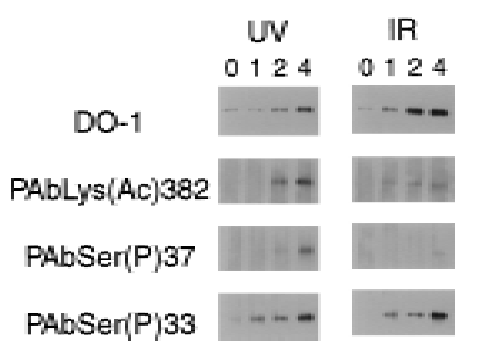

Figure 8. Phosphorylation and acetylation of p53 in response to $U V$ and $\gamma$ radiation after ALLN treatment. A549 cells were treated with $20 \mu \mathrm{m}$ cal pain inhibitor I (ALLN) and $4 \mathrm{hr}$ later were exposed to $25 \mathrm{~J} / \mathrm{m}^{2}$ of UV-C or $8 \mathrm{~Gy} \gamma$-rays (IR). TSA was added to $5 \mu \mathrm{M}$ immediately after DNA damage treatment. Samples were harvested at the indicated times after DN A damage treatment (Lanes $0,1,2,4 \mathrm{hr}$ ), and extracts were immunoprecipitated and analyzed by western immunobloting as described in Fig. 7 and $M$ aterials and Methods. Blots were probed sequentially with PAbLys(Ac)382, PAbSer(P)33, PAbSer(P)37, and DO-1. 


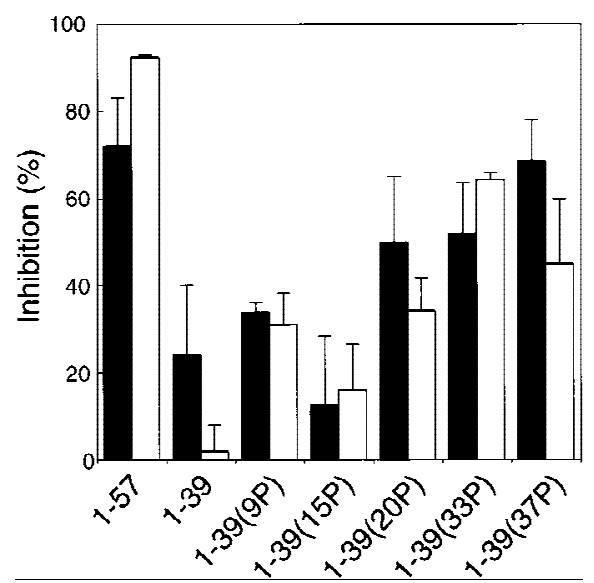

Figure 9. Inhibition of in vitro acetylation by PCAF (open bars) and p300 (solid bars) of full-length, wild-type p53 by p53 peptides. Assays were performed as described in Materials and M ethods and the radioactivity incorporated into wild-type p53 was quantitated with a Phosphorlmager and Imagequant software. Amino-terminal p53 peptides and phosphopeptides were present at $100 \mu \mathrm{m}$; the p53 substrate concentration was $0.1 \mu \mathrm{m}$. The results shown are an average of three independent assays for p300 (error bars, S.D.) and two independent assays for PCAF (error bars, range). Acetylation of the carboxy-terminal fragment p53(319-393) by p300 was not inhibited by these same aminoterminal peptides (data not shown).

the p53 amino terminus, but surprisingly, not by mutants that prevented tetramerization or by phosphorylation of Ser-378, which lies only six amino acids from the p300 acetylation site. In contrast, acetylation by PCAF was only modestly affected by removing the amino terminus, but was strongly influenced by conformation. Point mutants that prevent tetramerization dramatically decreased acetylation as did phosphorylation at Ser-378, a site potentially phosphorylated by PKC. Phosphorylation at Ser-392 had no significant effect. These findings suggest that recognition of p53 by p300 may depend in part on interactions with the p53 amino terminus, whereas at least in vitro, PCAF specifically recognized the tetrameric form of the carboxyl terminus, implying an interaction with this domain. In vivo p300 is tightly associated with the RNA polymerase II holoenzyme complex ( $\mathrm{N}$ akajima et al. 1997), and PCAF was reported to associate with p300 (Yang et al. 1996); thus, in vivo recognition of p53 by either HAT may be influenced by additional factors. Moreover, the general transcription factors for RNA polymerase II, TFIIE $\beta$ and TFIIF, are acetylated by PCAF, p300, and $\mathrm{TAF}_{\| 1} 250$, al though considerable specificity in substrate preference was apparent (Imhof et al. 1997). Interestingly, the site of acetylation in TFIIE $\beta$ by PCAF was identified as the lysine at residue 52 , which is in a sequence that is highly conserved among the human, Xenopus, and yeast homologs. Likewise, the sites acetylated by p300 and PCAF in p53 are in evolutionarily conserved segments, suggesting possible functional significance.

In vitro acetylation by either HAT activated sequencespecific DN A binding in the presence of a long competi- tor DN A, confirming the observations of Anderson et al . (1997) and suggesting that both acetylations may function, in part, by inactivating the nonsequence-specific binding activity of the p53 carboxyl terminus. M odifications to the carboxyl terminus that el iminate positively charged residues might be expected to have this effect. p300 and PCAF may further contribute differentially to transcriptional activation by weakening the interaction of chromosomal DNA with histones, thus facilitating the binding of transcription factors. Acetylation also could directly induce a conformational change in the carboxyl terminus that potentiates sequence-specific DN A binding by the central domain or influences interactions with other proteins that bind the carboxy-terminal domain, including TBP, XPB, XPD, CSB, S100b, CK2 $\beta$, or Brca 1 (for review, see Ko and Prives 1996; Ouchi et al. 1998). These interactions might be affected directly by acetylation of the carboxyl terminus, or through an acetylation-induced conformational change. Both acetylation sites are located in nuclear localization signals; thus, acetylation might al so affect nuclear import or export of $\mathrm{p} 53$.

To investigate the relevance of acetylation to p53 activation by DNA damage in vivo, we used antibodies specific for acetylated Lys-382 and Lys-320 in Western blot analyses of lysates from undamaged, damaged, and ALLN -treated cells. p53 levels dramatical ly increased in response to UV-C, IR, and ALLN; however, only DNA damage-causing agents gave a signal with the acetylation-specific antibodies. The lack of immunoreactivity in lysates from ALLN treated cells cannot be caused by lower amounts of p53 because there was an equivalent amount of p53 in lysates from damaged and ALLNtreated cells. Kinetic analyses showed that acetylation is an early event in the DNA damage response. The signal obtained with the PAbLys(Ac)382 antibody was readily detected by $2 \mathrm{hr}$ after IR, by $4 \mathrm{hr}$ after UV, and by $1 \mathrm{hr}$ after IR exposure in cells pretreated with ALLN to increase p53 levels. After UV irradiation, the signal continued to increase for $24 \mathrm{hr}$, consistent with the continued accumulation of p53 and the fact that UV-induced

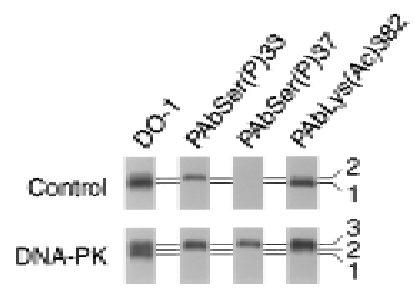

Figure 10. Phosphorylation by DNA-PK potentiates acetylation of human p53 by p300. Recombinant human p53 ( $250 \mathrm{ng}$ in $20 \mu \mathrm{l})$ purified from insect cells was incubated with purified DNA-PK (40 units), DN A, and ATP at $30^{\circ} \mathrm{C}$ for $1 \mathrm{hr}$ and then with recombinant $p 300(\sim 0.5 \mathrm{ng})$ and acetyl-CoA at $37^{\circ} \mathrm{C}$ for 20 min. Western blots of the reaction products were probed sequentially with PAbLys(Ac)382, PAbSer(P)33, PAbSer(P)37, and DO-1. N ote that incubation with DNA-PK produced a new p53 isoform (label ed 3) that is phosphorylated on Ser-37 as well as on Ser-33. This isoform was preferentially acetylated by p300. 
damage is repaired slowly (Dumaz et al. 1997). The signal obtained with the PAbLys(Ac)320 antibody after UV irradiation was weaker than that with the PAbLys(Ac)382 antibody, possibly indicating that less p53 becomes acetylated at Lys-320 compared with Lys-382. Nevertheless, the Lys-320 signal also increased with time after treatment; however, after IR, acetylation of Lys-320 was seen only at $24 \mathrm{hr}$, suggesting that it may not play a role in activating p53 in response to DNA strand breaks. These data clearly provide, for the first time, a potential mechanism for coupling the regulation of p53's activity as a transcription factor with acetylation. Our data further show that p53 accumulation and acetylation are not directly coupled, and that agents which produce different types of DNA damage may differ in their ability to induce p53 acetylation at individual sites. Determining the exact role of acetylation in the cytostatic and apoptotic responses must await the creation of p53 mutants at the acetylated sites, stable cell lines that express them, and a comparison of p53-mediated functions with acetylation in response to stress-inducing agents.

p53 is stabilized and activated in response to DNA damage by two at least partially independent pathways, one of which responds to DNA double-strand breaks (DSBs), the major DNA damage caused by IR, the other of which is activated by bulky lesions in DNA such as those caused by exposure to UV light (for review, see Agarwal et al. 1998). Phosphorylation is widely believed to be a major mechanism for regulating these effects. The DSB activation pathway depends on the function of the ATM (ataxia telangiectsia) gene product, a member of the DN $\bar{A}-P K$ class of large serine/threonine protein kinases that have homology with phosphatidylinositol kinases (Khanna and Lavin 1993). p53 becomes phosphorylated on Ser-15 in response to both UV and IR (Siliciano et al. 1997), and ATM was shown recently to be activated in response to IR and to directly phospharylate Ser-15 of human p53, suggesting that it is likely to be involved in activating p53 in response to DNA strand breaks (Banin et al. 1998; Canman et al 1998). Detection of bulky lesions including pyrimidine dimers is independent of ATM and appears to be accomplished, at least in part, by components of the transcription apparatus (Dumaz et al. 1997). However, DN A damage-inducing agents such as UV light al so activate other cellular response pathways, including the Jun amino terminal kinase (JNK) pathway. JNK kinases phosphorylate mouse p53 at Ser-34, and in vivo this serine is phosphorylated in response to exposing cells to UV-C (Milne et al. 1995), possibly implicating JNK kinases in a response to UV-C that is independent of direct DNA damage (Herrlich et al. 1997). The homologous human residue is Ser-33. Phosphorylation of Ser-15 and Ser-37 inhibits binding by Mdm2, implicating these modifications in stabilizing p53 in response to DN A damage (Haupt et al. 1997; Kubbutat et al. 1997; Shieh et al. 1997); however, p53 can be activated as a transcription factor without significantly accumulating (Huang et al. 1996; Haapajärvi et al. 1997; Chernov et al. 1998). Sequence-specific binding can be activated by phosphorylation of Ser-315, Ser-378, and Ser-392 (Hupp et al. 1992; Hupp and Lane 1995; Takenaka et al. 1995; Wang and Prives 1995; Kapoor and Lozano 1998); however, none of these modifications were shown to occur in response to DN A damage.

In vitro p53 interacts with p300 through its aminoterminal domain (Gu et al. 1997), and residues between Leu-22 and Phe-54 are critical for this interaction (Scolnick et al . 1997). p53 and p300 al so col ocal ize within the nucleus and coexist as a stable DNA-binding complex (Lill et al. 1997). CBP/p300 are coactivators for p53-specific transcription, and activation of p53-specific transcription by $\mathrm{p} 300$ is potentiated by IR (Avantaggiati et al. 1997). Our finding that full-length p53 is a better substrate for p300 than is a tetrameric carboxy-terminal fragment (Fig. 1) is consistent with an importance of amino-terminal p53 residues for acetylation of the carboxyl terminus. To expl ore further a role for phosphorylation in modul ating acetylation, we examined the effect of phosphorylated amino-terminal p53 peptides on the ability of p300 and PCAF to acetylate full-length p53 in vitro. Acetylation of full-length p53, but not a carboxyterminal fragment, was significantly inhibited by phosphorylated p53 amino-terminal peptides compared with nonphosphorylated controls. Furthermore, p53 phosphorylated by DNA-PK was preferentially acetylated by p300. These data cl early suggest that the amino-terminal p53 phosphorylations affect the ability of these HATs to acetylate p53. We also show for the first time that p53 becomes phosphorylated at Ser-33 and Ser-37 in response to either IR or UV light, consistent with a role for these phosphorylations in promoting the acetylation of p53. Our finding that phosphorylation at Ser-37 of p53 in UVirradiated cells is prolonged compared with cells treated with IR indicates that UV irradiation and $\gamma$ irradiation may have different effects on the specific kinases that phosphorylate this site.

Our data, in conjunction with previous studies, suggest a model in which DNA damage activates p53 as a transcription factor through a cascade of post-translational modifications that include both phosphorylations and acetylations (Fig. 11). Phosphorylation of Ser-15 and Ser-37 at the amino terminus of p53 prevents $\mathrm{Mdm} 2$ binding, thus stabilizing p53. DN A damage also induces phosphorylation at additional amino-terminal residues, including Ser-33 (a JN K site) and Ser-37 (a DN A-PK site), which increase p53's affinity for p300 and PCAF, thus promoting acetylation of carboxy-terminal sites including Lys-382 (by p300) and Lys-320 (by PCAF). Acetylation at either site inhibits nonspecific DNA-binding, thereby al lowing sequence-specific DNA-binding. Alternatively or in addition, acetylation may cause a conformational change that promotes sequence-specific binding through the central domain. This simplified model shows one way that p53 may be activated as a transcripti on factor in response to a DN A damage-inducing agent. p53 is modified at several additional sites, and these may function independently or in conjunction with acetylation to activate p53 in response to UV or other agents; modifications to other components al so may be important. 


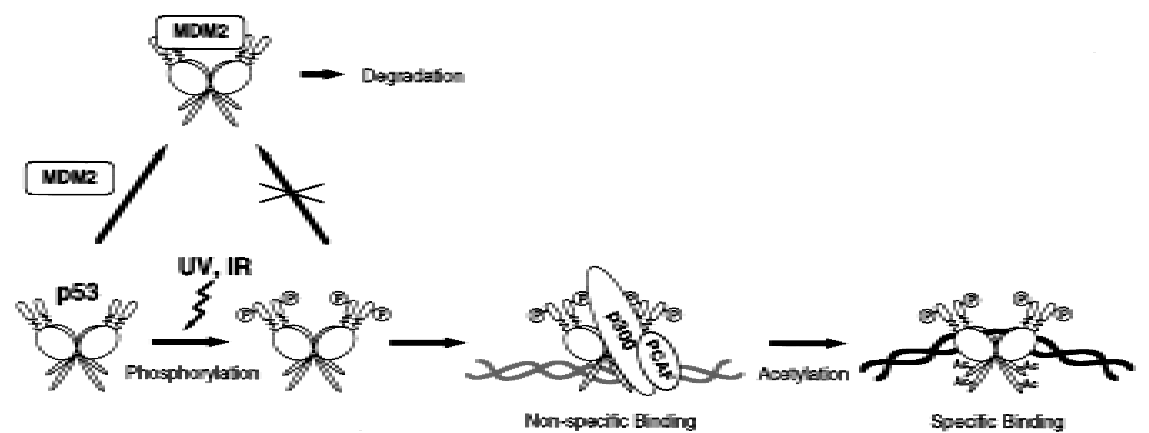
model incorporates recent findings from other studies including the role of phosphorylation in regulating p53's interaction with mdm2 (Shieh et al. 1997), induction of amino-terminal phosphorylation by UV, IR, and other agents (Siliciano et al. 1997), and the effect of p53's nonspecific interaction with DN A on sequence-specific DNA binding (Anderson et al. 1997).

\section{Material and methods}

\section{Cell lines}

A549 (ATCC CCL-185), a human lung carcinoma cell line with wild-type p53, and HCT116 (ATCC CCL-247), a human colon carcinoma cell line with wild-type p53, were obtained from the American type culture collection (Rockville, MD). The cells were grown in Dulbecco's modified Eagle medium (GIBCOBRL, Bethesda, MD) supplemented with $10 \%$ fetal bovine serum (Biowhittaker, Wakerville, MD) and penicillin/streptomycin (GIBCO-BRL) in a humidified atmosphere with $5 \% \mathrm{CO}_{2}$.

Enzymes, substrates, and peptides

Recombinant Flag-tagged human PCAF and p300 were prepared as described (Y ang et al. 1996); acetyl-CoA and CoA were from Sigma Chemical Co.; [1- ${ }^{14} \mathrm{C}$ ]acetyl-CoA (55 mCi/mM ole) was from Amersham, Inc. Full-length, His-tagged wild-type human p53 protein and p53 fragments p53(283-393) and p53(318-393) were produced by use of a baculovirus expression system (Anderson et al. 1997) and were provided by M. A nderson and P. Tegtmeyer (SUNY, Stony Brook). The carboxy-terminal p53 fragment p53(319-393) and modified versions thereof were synthesized by the fragment condensation method by use of thioesters (Sakamoto et al. 1996). All other peptides were synthesized by the solid-phase method with Fmoc chemistry by an Applied Biosystems 430A peptide synthesizer (Foster City, CA). Phosphoserine residues were incorporated as Fmoc-Ser[PO(OBzl)OH]$\mathrm{OH}$ ( $\mathrm{N}$ ovabiochem, San Diego, CA). The peptide was cleaved from the resin and side-chain-protecting groups were removed with reagent $\mathrm{K}$ (TFA/phenol/thioanisole/ $\mathrm{H}_{2} \mathrm{O} /$ EDT $=82.5: 5: 5$ : 5:2.5) for $3 \mathrm{hr}$ at room temperature. The p53(1-39) peptides were purified by HPLC on a pH-stable Vydac C-8 column (Hesperia, $\mathrm{CA}$ ) with $0.2 \%$ hexafluoroacetone- $\mathrm{N}_{4} \mathrm{OH}$ at $\mathrm{pH} 7.0$ /acetonitrile. The mass of peptides were confirmed by el ectrospray ionization mass spectrometry on a Finnigan MAT SSQ 7000 (Finnigan MAT, San Jose, CA).

Acetylation- and phosphorylation-specific p53 antibodies

Rabbit polyclonal antibodies specific for p53 acetylated at Lys320 [PAbLys(Ac)320] or Lys-320 [PAbLys(Ac)382] were raised against the human p53 sequence Ac-377-387(382Ac)Cys [i.e., Ac-SPQPKK(AC)-KPLDGC] or Ac-315-325(320Ac)Cys [i.e., AcTSRHKK(AC)-LM FKTC] conjugated through the added carboxyterminal cysteine to KLH (keyhole limpet hemocyanin). Sera from immunized rabbits were affinity purified by use of each acetylated peptide coupled with SulfoLink (Pierce). The purified antibodies then were passed through a column coupled with the respective unacetylated peptide to deplete antibodies that react with unacetylated p53. Specificity was shown by use of unacetylated, baculovirus-produced, wild-type p53 or p53 acetylated in vitro (Fig. 6). Antibodies specific for p53 phosphorylated at Ser-33 or Ser-37 were prepared similarly. Rabbits were immunized with the p53 phosphopeptide Ac-27-39(33P)Cys [i.e., Ac-PEN N VLS(P)-PLPSQAC ] or Ac-32-43(37P)Cys [i.e., AcLSPLPS(P)-QAM DDLC ], and phosphorylation site-specific antibodies were affinity purified by use of the corresponding SulfoLinked phosphorylated peptides. In ELISA and immunoblot assays, the purified PA bSer(P)33 antibody recognized the immunizing peptide and p53(1-39) phosphorylated at Ser-33 but not p53(1-39) phosphorylated at Ser-9, Ser-15, Ser-20, or Ser-37, whereas the PAbSer(P)37 antibody recognized p53(1-39) and p53(25-65) when phosphorylated at Ser-37 but not either unphosphorylated peptide nor p53(1-39) phosphorylated at ser-15 (data not shown).

\section{Enzymatic assay of HAT}

All assays were performed in buffer $\mathrm{A}[50 \mathrm{~mm}$ Tris- $\mathrm{HCl}(\mathrm{pH} 8.0)$, 10\% glycerol (vol/vol), $1 \mathrm{~mm}$ DTT, $0.1 \mathrm{~mm}$ EDTA, $10 \mathrm{~mm} \mathrm{Na}$ butyrate] as described (Herrera et al . 1997). Substrate concentrations were $0.1-0.25 \mathrm{mg} / \mathrm{ml}$ and $\left[1-{ }^{14} \mathrm{C}\right]$ acetyl-CoA concentrations were at 9-15 $\mu \mathrm{m}$, unless otherwise indicated. Acetyltransferase reactions for mass spectral sequence analyses and for DNA-binding studies were performed in the same manner except that the acetyl-CoA was not radioactive. Assays were incubated at $37^{\circ} \mathrm{C}$ and initiated by adding either the protein substrate to a mixture containing the acetyltransferase and acetylCoA in buffer $A$ or by adding the acetyltransferase to a mix containing the protein substrate and acetyl-CoA in buffer A. Incorporation of $\left[1-{ }^{14} \mathrm{C}\right]$ acetyl-CoA was quantitated after SDSPAGE with a Phosphorlmager (M olecular Dynamics).

\section{Mass spectrometric analysis}

Bacterium-expressed p53(319-393) was acetylated by either PCAF or p300 in buffer A as described above, except that the reaction time was extended to $4 \mathrm{hr}$, adding fresh enzyme every hour and also $10 \mu \mathrm{m}$ of acetyl-CoA with the final addition of enzyme. After acetylation, the peptide was purified by HPLC and the mass of the peptide was analyzed by use of a single quadrupole mass spectrometer (Finnigan model SSQ-7000) equipped with an el ectrospray ion source.

To identify the acetylated site on p53(319-393), the purified peptide was digested with trypsin (Promega), and the resulting 
fragments were analyzed by ion-trap mass spectrometry (Finnigan model LCQ) equipped with a nanospray ion source. Purified synthetic peptides were used to confirm the molecular masses.

\section{DNA-binding assay}

DN A-binding assays were performed as described (Anderson et al. 1997) with $2 \mathrm{ng}$ per $20-\mu \mathrm{l}$ assay of labeled, 30-bp doublestranded, p53-specific probe sequence (5'-ctagAGCGGACATGCCCGGGCATGTCCGCG-3'/ 3'-TCGCCTGTADGGGCCCGTACAGGCGCagct-5') (Funk et al. 1992), and 10 ng of pBluescript plasmid DNA as a nonspecific competitor.

\section{Peptide inhibition studies}

Assays were performed as described above except that the enzyme(s) were added to a mixture containing wild-type p53 at 0.1 $\mu \mathrm{M}$ and competing peptides were at $100 \mu \mathrm{m}$, and the concentration of enzyme was reduced to $0.01 \mu \mathrm{g} / \mu \mathrm{l}$ for PCAF and $5 \mathrm{ng} / \mu \mathrm{l}$ for p300. The incorporation of $\left[{ }^{14} \mathrm{C}\right]$ acetate into p53 was measured by use of Phosphorlmager analysis of the Enhance-impregnated (Dupont) SDS-polyacrylamide gels by use of Imagequant software (M olecular Dynamics, Inc.).

Induction of DNA damage and detection

of p53 post-translational modifications

Cells were seeded $24 \mathrm{hr}$ prior to treatment and were $60 \%-70 \%$ confluent at the time of treatment. After washing twice with PBS, cells were exposed to UV irradiation with a Stratagene UV Stratal inker 2400. IR experiments were performed with a Shepherd $\mathrm{M}$ ark I ${ }^{137} \mathrm{C}$ s irradiator at a dose rate of $3.2 \mathrm{~Gy}$ per minute. The proteosome inhibitor ALLN (Calbiochem) was added to cells at a final concentration of $20 \mu \mathrm{m}$ as described (Siliciano et al. 1997). The deacetylase inhibitor TSA (WAKO) was added at a final concentration of $5 \mu \mathrm{M}$ immediately after DN A damage or ALLN treatment. In a preliminary experiment similar to that shown in Figure 7, no signal was observed after DNA damage with either acetylation-specific antibody when TSA was omitted.

Cultures were harvested at the indicated times, washed twice with ice-cold PBS, and lysed on ice in ice-cold lysis buffer (50 $\mathrm{mm}$ Tris- $\mathrm{HCl}$ at $\mathrm{pH} 7.5,5 \mathrm{~mm}$ EDTA, $50 \mathrm{~mm} \mathrm{NaCl}, 1 \%$ Triton $\mathrm{X}-100,50 \mathrm{~mm} \mathrm{~N}$ aF, $10 \mathrm{~mm}$ sodium pyrophosphate, $1 \mathrm{~mm}$ sodium orthovanadate, $10 \mu \mathrm{g} / \mathrm{ml}$ aprotinin, $10 \mu \mathrm{g} / \mathrm{ml}$ leupeptin, $5 \mu \mathrm{g} /$ $\mathrm{ml}$ pepstatin, $0.5 \mathrm{~mm}$ PMSF, and $5 \mu \mathrm{M}$ TSA). Lysates were clarified at $20,000 \mathrm{~g}$ for $30 \mathrm{~min}$ at $4^{\circ} \mathrm{C}$. Before immunoprecipitation, each sample (containing $1.3 \mathrm{mg}$ of total cellular protein) was precleared by protein G-Sepharose (GammaBind Plus Sepharose, Pharmacia) for $1 \mathrm{hr}$; then $2.5 \mu \mathrm{g}$ of affinity-purified mouse monoclonal anti-p53 antibody (A b-2, Cal biochem) was added. Immunoprecipitation reactions were incubated on ice for $1 \mathrm{hr}$, protein G-Sepharose was added, and lysates were further incubated at $4^{\circ} \mathrm{C}$ for $1 \mathrm{hr}$, with rotation. The beads were collected by centrifugation and then washed five times with ice-cold lysis buffer. The immunoprecipitates were dissolved in $2 \times$ SDS sample buffer $(125 \mathrm{~mm}$ Tris- $\mathrm{HCl}$ at $\mathrm{pH} 6.8,20 \%$ glycerol, $5.2 \%$ SDS, and $0.05 \%$ bromophenol blue) and boiled for $3 \mathrm{~min}$. Electrophoresis was on a 10\% SDS-polyacrylamide gel. After separation, proteins were electrophoretically transferred to PVDF (polyvinylidene difluoride) membranes. Blocking was performed with a $5 \%$ solution of reconstituted dried milk powder for $2 \mathrm{hr}$ at room temperature. Primary antibodies, PAbLy$\mathrm{s}(\mathrm{Ac}) 320, \mathrm{PA}$ bLys(Ac)382, and affinity-purified mouse monoclonal antibody to p53 (Ab-6, Calbiochem), were incubated with the blot for $1 \mathrm{hr}$ at room temperature. Detection was by the enhanced chemiluminescence method (ECL, Amersham) with the appropriate peroxidase-conjugated secondary antibody.

\section{Acknowledgments}

We are indebted to P. Tegtmeyer for gifts of reagents, and to M.E. Anderson, C.A. Pise-M asison, and Y. Nakatani for advice and suggestions. C.W.A. is supported by U. S. Public Health Services grant GM 52825 and by the Office of Health and Environmental Research of the U.S. Department of Energy.

The publication costs of this article were defrayed in part by payment of page charges. This article must therefore be hereby marked 'advertisement' in accordance with 18 USC section 1734 solely to indicate this fact.

\section{References}

Agarwal, M.L., W.R. Taylor, M.V. Chernov, O.B. Chernova, and G.R. Stark. 1998. The p53 network. J. Biol. Chem. 273: 1-4.

Anderson, M.E., B. Woelker, M. Reed, P. Wang, and P. Tegtmeyer. 1997. Reciprocal interference between the sequencespecific core and nonspecific C-terminal DNA binding domains of p53: implications for regulation. Mol. Cell Biol. 17: 6255-6264.

Avantaggiati, M.L., V. Ogryzko, K. Gardner, A. Giordano, A.S. Levine, and K. Kelly. 1997. Recruitment of p300/CBP in p53dependent signal pathways. Cell 89: 1175-1184.

Banin, S., L. Moyal, S.-Y. Shieh, Y. Taya, C.W. Anderson, L. Chessa, N .I. Smorodinsky, C. Prives, Y. Reiss, Y. Shiloh, and Y. Ziv. 1998. Enhanced phosphorylation of p53 by ATM in response to DNA damage. Science (in press).

Canman, C.E., D.-S. Lim, K.A. Cimprich, Y. Taya, K. Tamai, K. Sakaguchi, E. A ppella, M.B. Kastan, and J.D. Siliciano. 1998. Activation of the ATM kinase by ionizing radiation and phosphorylation of p53. Science (in press).

Chernov, M.V., C.V. Ramana, V.V. Adler, and G.R. Stark. 1998. Stabilization and activation of p53 are regulated independently by different phosphorylation events. Proc. Natl. Acad. Sci. 95: 2284-2289.

Dumaz, N., A. Duthu, J.C. Ehrhart, C. Drougard, E. Appella, C.W. Anderson, P. May, A. Sarasin, and L. Daya-Grosjean. 1997. Prolonged p53 protein accumulation in trichothiodystrophy fibroblasts dependent on unrepaired pyrimidine dimers on the transcribed strands of cellular genes. Mol. Carcinog. 20: 340-347.

El-Deiry, W.S., T. Tokino, V.E. Velculescu, D.B. Levy, R. Parsons, J.M. Trent, D. Lin, W.E. Mercer, K.W. Kinzler, and B. Vogelstein. 1993. WAF1, a potential mediator of p53 tumor suppression. Cell 75: 817-825.

Funk, W.D., D.T. Pak, R.H. Karas, W.E. Wright, and J.W. Shay. 1992. A transcriptionally active DNA-binding site for human p53 protein complexes. Mol. Cell. Biol. 12: 2866-2871.

$\mathrm{Gu}$, W. and R.G. Roeder. 1997. Activation of p53 sequencespecific DNA binding by acetylation of the p53 C-terminal domain. Cell 90: 595-606.

Gu, W., X.-L. Shi, and R.G. Roeder. 1997. Synergistic activation of transcription by CBP and p53. Nature 387: 819-823.

Haapajärvi, K. Pitkänen, M. Tsubari, and M. Laiho. 1997. p53 transactivation and protein accumulation are independently regulated by UV light in different phases of the cell cycle. Mol. Cell Biol. 17: 3074-3080.

Haupt, Y., R. Maya, A. Kazaz, and M. Oren. 1997. Mdm2 promotes the rapid degradation of p53. Nature 387: 296-299.

Hermeking, H., C. Lengauer, K. Polyak, T.-C. He, L. Zhang S. Thiagalingam, K.W. Kinzler, and B. Vogelstein. 1997. 14- 
3-3 $\sigma$ is a p53-regulated inhibitor of G2/M progression. Mol. Cell 1: 3-11.

Herrera, J.E., M. Bergel, X.-J. Y ang, Y. N akatani, and M. Bustin. 1997. The histone acetyltransferase activity of human GCN 5 and PCAF is stabilized by coenzymes. J. Biol. Chem. 272: 27253-27258.

Herrlich, P., C. Blattner, A. Knebel, K. Bender, and H.J. Rahmsdorf. 1997. Nuclear and non-nuclear targets of genotoxic agents in the induction of gene expression. Shared principles in yeast, rodents, man and plants. Biol. Chem. 378: 12171229.

Huang, L.C., K.C. Clarkin, and G.M. Wahl. 1996. Sensitivity and selectivity of the DNA damage sensor responsible for activating p53-dependent G1 arrest. Proc. Natl. Acad. Sci. 93: 4827-4832.

Hupp, T.R. and D.P. Lane. 1995. Two distinct signaling pathways activate the latent DNA-binding function of p53 in a casein kinase II-independent manner. J. Biol. Chem. 270: 18165-18174.

Hupp, T.R., D.W. Meek, C.A. Midgley, and D.P. Lane. 1992. Regulation of the specific DN A-binding function of p53. Cell 71: 875-886.

Imhof, A., X.-J. Yang, V.V. Ogryzko, Y. N akatani, A.P. Wolffe, and H. Ge. 1997. A cetylation of general transcription factors by histone acetyltransferases. Curr. Biol. 7: 689-692.

Juven, T., Y. Barak, A. Zauberman, D.L. George, and M. Oren. 1993. Wild type p53 can mediate sequence-specific transactivation of an internal promoter within the mdm 2 gene. Oncogene 8: 3411-3416.

Kapoor, M. and G. Lozano. 1998. Functional activation of p53 via phosphorylation following DNA damage by UV but not $\gamma$ radiation. Proc. Natl. Acad. Sci. 95: 2834-2837.

Khanna, K.K. and M.F. Lavin. 1993. Ionizing radiation and UV induction of p53 protein by different pathways in ataxiatel angiectasia cells. Oncogene 8: 3307-3312.

Ko, L.J. and C. Prives. 1996. p53: Puzzle and paradigm. Genes \& Dev. 10: 1054-1072.

Kubbutat, M.H.G., S.N. Jones, and K.H. Vousden. 1997. Regulation of p53 stability by M dm2. Nature 387: 299-303.

Lees-Miller, S.P., K. Sakaguchi, S.J. Ullrich, E. Appella, and C.W. Anderson. 1992. Human DNA-activated protein kinase phosphorylates serines 15 and 37 in the amino-terminal transactivation domain of human p53. Mol. Cell Biol. 12: 5041-5049.

Levine, A.J. 1997. p53, the cellular gatekeeper for growth and division. Cell 88: 323-331.

Lill, N.L., S.R. Grossman, D. Ginsberg, J. DeCaprio, and D.M. Livingston. 1997. Binding and modulation of p53 by p300/ CBP coactivators. Nature 387: 823-827.

Mayo, L.D., J.J. Turchi, and S.J. Berberich. 1997. Mdm-2 phosphorylation by DNA-dependent protein kinase prevents interaction with p53. Cancer Res. 57: 5013-5016.

Meek, D.W. 1998. Multisite phosphorylation and the integration of stress signals at p53. Cell Signal 10: 159-166.

Milne, D.M., L.E. Campbell, D.G. Campbell, and D.W. Meek. 1995. p53 is phosphorylated in vitro and in vivo by an ultraviolet radiation-induced protein kinase characteristic of the c-Jun kinase, JN K1. J. Biol. Chem. 270: 5511-5518.

Nakajima, T., C. U chida, S.F. Anderson, C.-G. Lee, J. Hurwitz, J.D. Parvin, and M. Montminy. 1997. RNA helicase A me diates association of CBP with RNA polymerase II. Cell 90: 1107-1112.

Oliner, J.D., J.A. Pietenpol, S. Thiagalingam, J. Gyuris, K.W. Kinzler, and B. Vogelstein. 1993. Oncoprotein MDM 2 conceals the activation domain of tumour suppressor p53. Nature 362: 857-860.
Ouchi, T., A.N .A. M onteiro, A. August, S.A. Aaronson, and H. Hanafusa. 1998. BRCA1 regulates p53-dependent gene expression. Proc. Natl. Acad. Sci. 95: 2302-2306.

Patterson, R.M., C. He, J.K. Selkirk, and B.A. Merrick. 1996. Human p53 expressed in baculovirus-infected Sf9 cells displays a two-dimensional isoform pattern identical to wildtype p53 from human cells. Arch. Biochem. Biophys. 330: 71-79.

Pavletich, N.P., K.A. Chambers, and C.O. Pabo. 1993. The DNA-binding domain of p53 contains the four conserved regions and the major mutation hot spots. Genes \& Dev. 7: 2556-2564.

Perry, M.E., J. Piette, J.A. Zawadzki, D. Harvey, and A.J. Levine. 1993. The $\mathrm{mdm}-2$ gene is induced in response to UV light in a p53-dependent manner. Proc. Natl. Acad. Sci. 90: 1162311627.

Pitkänen, K., T. Haapajärvi, and M. Lai ho. 1998. U.V.C.-induction of p53 activation and accumulation is dependent on cell cycle and pathways involving protein synthesis and phosphorylation. Oncogene 16: 459-469.

Sakamoto, H., M.S. Lewis, H. Kodama, E. Appella, and K. Sakaguchi. 1994. Specific sequences from the carboxyl terminus of human p53 gene product form anti-parallel tetramers in solution. Proc. Natl. Acad. Sci. 91: 8974-8978.

Sakamoto, H., H. Kodama, Y. Higashimoto, M. Kondo, M.S. Lewis, C.W. Anderson, E. Appella, and K. Sakaguchi. 1996. Chemical synthesis of phosphorylated peptides of the carboxy-terminal domain of human p53 by a segment condensation method. Int. J. Pept. Protein Res. 48: 429-442.

Scolnick, D.M., N.H. Chehab, E.S. Stavridi, M.C. Lien, L. Caruso, E. Moran, S.L. Berger, and T.D. Halazonetis. 1997. CREB-binding protein and p300/CBP-associated factor are transcriptional coactivators of the p53 tumor suppressor protein. Cancer Res. 57: 3693-3696.

Shieh, S.-Y., M. Ikeda, Y. Taya, and C. Prives. 1997. DN A damage-induced phosphorylation of p53 alleviates inhibition by MDM2. Cell 91: 325-334.

Siliciano, J.D., C.E. Canman, Y. Taya, K. Sakaguchi, E. A ppella, and M.B. Kastan. 1997. DNA damage induces phosphorylation of the amino terminus of p53. Genes \& Dev. 11: 34713481.

Takenaka, I., F. M orin, B.R. Seizinger, and N. Kley. 1995. Regulation of the sequence-specific DN A-binding function of p53 by protein kinase $C$ and protein phosphatases. J. Biol. Chem. 270: 5405-5411.

Wang, Y. and C. Prives. 1995. Increased and altered DN A binding of human p53 by $\mathrm{S}$ and $\mathrm{G} 2 / \mathrm{M}$ but not $\mathrm{G} 1$ cyclin-dependent kinases. Nature 376: 88-91.

Wang, Y., M. Reed, P. Wang, J.E. Stenger, G. M ayr, M .E. Anderson, J.F. Schwedes, and P. Tegtmeyer. 1993. p53 domains: Identification and characterization of two autonomous DN A-binding regions. Genes \& Dev. 7: 2575-2586.

Wu, X., J.H. Bayle, D. Olson, and A.J. Levine. 1993. The p53mdm-2 autoregulatory feedback loop. Genes \& Dev. 7: 1126-1132.

Yang, X.-J., V.V. Ogryzko, J.-i. Nishikawa, B.H. Howard, and Y. Nakatani. 1996. A p300/CBP-associated factor that competes with the adenoviral oncoprotein E1A. Nature 382: 319-324.

Yoshida, M., M. Kijima, M. Akita, and T. Beppu. 1990. Potent and specific inhibition of mammalian histone deacetylase both in vivo and in vitro by trichostatin A. J. Biol. Chem. 265: 17174-17179. 


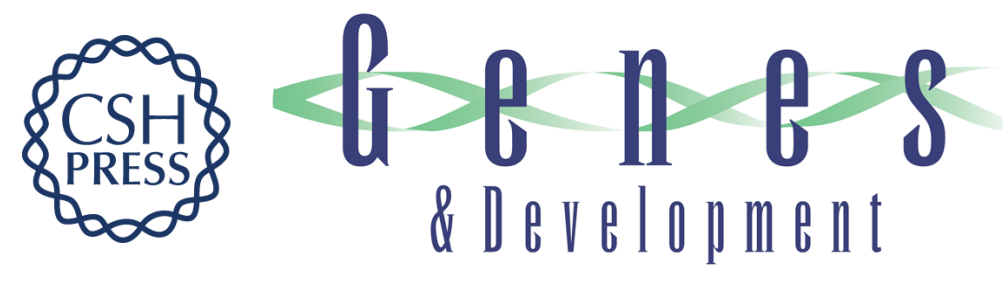

\section{DNA damage activates p53 through a phosphorylation-acetylation cascade}

Kazuyasu Sakaguchi, Julio E. Herrera, Shin'ichi Saito, et al.

Genes Dev. 1998, 12:

Access the most recent version at doi:10.1101/gad.12.18.2831

References This article cites 47 articles, 23 of which can be accessed free at: http://genesdev.cshlp.org/content/12/18/2831.full.html\#ref-list-1

License

Email Alerting

Receive free email alerts when new articles cite this article - sign up in the box at the top Service right corner of the article or click here.

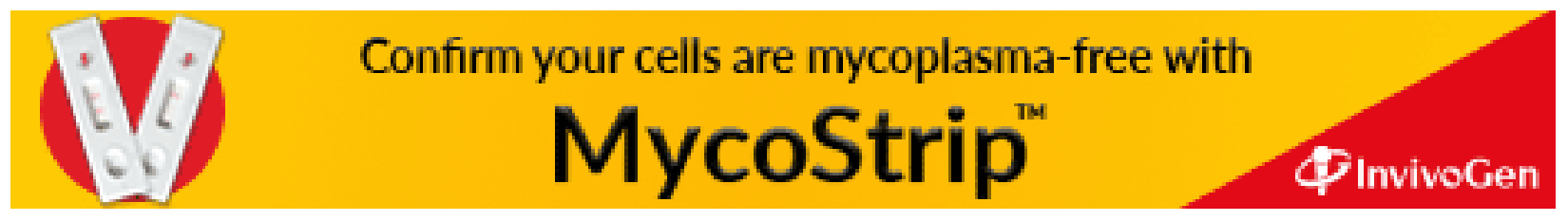

